\title{
EDITORIAL
}

\section{FOLLOWING KOCH'S EXAMPLE}

\author{
As 2005 marks the 100th anniversary of Robert Koch receiving the Nobel Prize for his work on \\ tuberculosis, what could microbiologists today learn from him?
}

Robert Koch (1843-1910) is one of the founding fathers of medical microbiology and is probably most well known for his guidelines for establishing a microorganism as the causative agent of an infectious disease. The principles behind Koch's postulates are still considered relevant today, although subsequent developments, such as the discovery of microorganisms that cannot grow in cell-free culture, including viruses and obligate intracellular bacterial pathogens, have caused the guidelines themselves to be reinterpreted for the molecular $\mathrm{era}^{1-3}$.

The details of Koch's research career and his contribution to microbiology have recently been elegantly recounted by Stefan Kaufmann and colleagues ${ }^{4,5}$. Here, we thought it would be interesting to look at Koch's career with the aim of devising an alternative version of Koch's postulates, this time for microbiologists rather than microorganisms - that is, what are the characteristics of Koch's approach to research that could spell success for microbiologists today? In our opinion, the three qualities that stand out are his multidisciplinary approach, his persistence and his teaching ability.

Koch's postulates aside, Robert Koch is also known for his work on the aetiology of anthrax and tuberculosis. In 1876, Koch published a paper giving the first demonstration that a living microorganism (Bacillus anthracis) was the causative agent of an infectious disease (anthrax) and in 1882, he isolated Mycobacterium tuberculosis and proved it was the causative agent of tuberculosis. Perhaps less well known is the fact that he discovered Vibrio cholerae, the causative agent of cholera, and was among the first to develop and implement public-health measures to control the disease, and that he also worked extensively on tropical diseases including African trypanosomiasis and malaria.

Contrary to what one might have expected for the nineteenth century, Koch did not have a privileged background. He was the third son of 13 children who taught himself to read and had to work hard to reach university. Even once he had qualified as a doctor, Koch's success did not come easily. His research on anthrax was carried out in his spare time in a primitive laboratory at home. Undaunted by his lack of facilities, Koch improvised materials where possible and, in addition to his description of anthrax, he made major strides in developing solid culture media and staining techniques, which would be instrumental in his discovery of M. tuberculosis. Working outside the university system, Koch was aware that it would be difficult to be taken seriously and, in a move that will be familiar to students and postdocs today, he actively sought the patronage of a well known researcher, not only to validate his work, but also to help him get it published. Koch's persistence paid off and the publication of his work on anthrax marked the start of his movement into the scientific elite in Germany.

In setting out Koch's postulates, Robert Koch was not only attempting to establish guidelines for his peers to follow but also wanted to influence their thinking and persuade them that the use of more rigorous criteria to prove that microorganisms cause disease was required to win over the sceptics. Once established in Germany, Koch was generous with his knowledge and techniques and nurtured the careers of many researchers who went on to become prominent figures in their own right, including Paul Erlich.

These days, of course, access to higher education in many countries is more open, and it would be unusual for even the biggest microbiology laboratories to work on such a diverse group of organisms. However, it is apparent that the principles that were important to Robert Koch still ring true: cast your net wide, work hard and pass on your knowledge to others.

\footnotetext{
1. Falkow, S. Molecular Koch's postulates applied to microbial pathogenicity. Rev. Infect. Dis. 10, S274-S276 (1988).

2. Fredericks, D. N. \& Relman, D. A. Sequence-based identification of microbial pathogens: a reconsideration of Koch's postulates. Clin. Microbiol. Rev. 9, 18-33 (1996).

3. Falkow, S. Molecular Koch's postulates applied to bacterial pathogenicity - a personal recollection 15 years later. Nature Rev. Microbiol. 2, 67-72 (2004).

4. Kaufmann, S. H. E. \& Schaible, U. E. 100th anniversary of Robert Koch's Nobel Prize for the discovery of the tubercle bacillus. Trends Microbiol. 13, 469-475 (2005).

5. Kaufmann, S. H. E. \& Winau, F. From bacteriology to immunology: the dualism of specificity. Nature Immunol. 11, 1063-1066 (2005).
} 